\title{
Integrating Soybean Residues With Nitrogen Fertilizer for Improved Maize Production in Eastern Uganda
}

\author{
B. Sadina ${ }^{1}$, A. Amoding ${ }^{2}$, R. Amayo ${ }^{1} \&$ M. Biruma ${ }^{1}$ \\ ${ }^{1}$ National Semi-Arid Resources Research Institute, Serere, Uganda \\ ${ }^{2}$ College of Agricultural and Environmental Sciences, Makerere University, Kampala, Uganda \\ Correspondence: B. Sadina, National Semi-Arid Resources Research institute (NaSARRI), P.O. Box 56, Soroti, \\ Serere, Uganda. E-mail: sadina.beatrice@gmail.com
}

Received: November 1, 2018

Accepted: April 3, $2019 \quad$ Online Published: June 15, 2019

doi:10.5539/jas.v11n8p206

URL: https://doi.org/10.5539/jas.v11n8p206

\begin{abstract}
Soybean has become one of the dominant crops in Ugandan farming systems; however the contribution of its residues to improve soil and crop productivity is less known. To investigate the role of soybean residues to enhance crop productivity, researcher-managed experiments were conducted for two seasons (2011B and 2012A) in Namayingo and Tororo districts, representing the L. Victoria crescent, and South-eastern L. Kyoga basin agro-ecological zones, respectively. Factorial treatments of three levels of soybean residues $\left(0,2\right.$ and $\left._{4} \mathrm{t} \mathrm{ha}^{-1}\right)$ and four levels of $\mathrm{N}$ fertilizer $\left(0,30,60\right.$ and $\left.120 \mathrm{~kg} \mathrm{ha}^{-1} \mathrm{~N}\right)$ in form of urea were applied in maize fields in a randomized complete block design so as to; determine the optimum nutrient combination for maize, and establish the added yield benefits, if any, of using soybean residues with $\mathrm{N}$ fertilizer in maize production. Site yields varied significantly $(\mathrm{p}<0.001)$, with higher maize yields obtained in Namayingo compared to Tororo. Significantly $(\mathrm{p}<0.05)$ higher maize grain yields were obtained with the highest nutrient input combinations of $2 \mathrm{t} \mathrm{ha}^{-1}$ residue and $60 \mathrm{~kg} \mathrm{ha}^{-1} \mathrm{~N}$ (yield increment of $71.72 \%$ above the control) in Namayingo district and $4 \mathrm{t} \mathrm{ha}^{-1}$ residue combined with $120 \mathrm{~kg} \mathrm{ha}^{-1} \mathrm{~N}$ increased maize grain yield by $140.69 \%$ above the control in Tororo. The added maize grain yield benefits ranged from $2540 \mathrm{~kg}_{\text {grain ha }}{ }^{-1}$ to $3250 \mathrm{~kg}$ grain ha ${ }^{-1}$ in Namayingo and from $2000 \mathrm{~kg}$ grain ha ${ }^{-1}$ to $2310 \mathrm{~kg}$ grain $\mathrm{ha}^{-1}$ in Tororo. Combined use of soybean residue with $\mathrm{N}$ fertilizer has been found to have agronomic yield benefits to maize production.
\end{abstract}

Keywords: added yield benefits, nutrients, soybean residue and maize

\section{Introduction}

Maize is a major staple crop in Eastern Africa (Kamanga et al., 2010; Kaizzi et al., 2012; Van Vugt, 2017), commonly grown either solely or integrated with legumes in a rotation and as an intercrop (Wortmann \& Ssali., 2001; Waha et al., 2013) to address the rapidly declining soil fertility that has threatened food security (Garrity et al., 2010) in the region. Several low input soil fertility management technologies such as use of improved fallow plant species like Mucuna pruriens, and Canvalia eniformis, cowpea rotation with sorghum, use of organic and inorganic ( $\mathrm{N}$ and $\mathrm{P}$ ) fertilizers and practicing reduced tillage are reported to increase crop yields (Kaizzi et al., 2007). More recently, biomass transfer systems of Tithonia diversifolia have also been reported to increase yields of staple crops like maize (Jama et al., 2000; Muna et al., 2013). However, the residues of Soybean as one of the upcoming dominant crops in a maize-legume cropping system has been under exploited as a soil input. The sobeans generates about $1.32 \mathrm{t} \mathrm{ha}^{-1}$ residues (FAOSTAT, 2010) which have been mostly used as bedding for livestock or burnt off in the field (Lal, 2005). Yet studies from within the East African region, particularly in Western Kenya, have indicated positive yield responses of maize when soybean residues are added to the fields together with inorganic fertilizers (Okalebo et al., 1999) in order to replenish soil fertility. Since fertilizer use is less affordable among most, especially small scale, maize farmers, the exploitation of the potential of such locally available organic crop residues that could enhance yields of maize in eastern Uganda needed to be explored. These residues may be used alone or as a supplement to inorganic fertilizers such as $\mathrm{N}$ fertilizer. Limited information exists on the use of the soybean residues as a source of soil amendment and neither the required amounts of $\mathrm{N}$ fertilizer that needs to be integrated with soybean residue nor the added yield benefits from combined application of soybean residue with $\mathrm{N}$ fertilizer are known for the maize-legume systems of Uganda. Therefore, this study was 
designed to determine the optimum combinations of soybean residue with $\mathrm{N}$ fertilizer needed to optimize maize production.

\section{Materials and Methods}

\subsection{Site Characteristics of the Study Areas}

The study was conducted in Namayuge village buswale sub county Namayingo district that represented the L. Victoria crescent agro ecological zone. Namayingo district is located at $00^{\circ} 17^{\prime} \mathrm{N}$ and $33^{\circ} 51^{\prime} \mathrm{E}$ at 1,200 meters above sea level. The L. Victoria crescent agro ecological zone lies at a mean altitude of 1,174 meters above sea level, with a sub-humid climate, bimodal rain fall pattern receiving rains of $>1200 \mathrm{~mm}$ and petric plinthsol soil type. The main food crops cultivated include maize, cassava, beans and sweet potatoes while robusta coffee is the major cash crop. The other site was Nyemnyemi village, Molo sub-county Tororo district representing the South and Eastern L. Kyoga basin. Tororo district is located at $00^{\circ} 45^{\prime} \mathrm{N}$ and $34^{\circ} 05^{\prime} \mathrm{E}$ at 1,185 meters above sea level. The South and Eastern L. Kyoga basin lies at a mean altitude of 1,075meters above sea level with a sub-humid climate, and bimodal rain fall pattern receiving rains averaging at $>1200 \mathrm{~mm}$. It has petric plinthsol soils where the main food crops include finger millet, banana and maize (Wortmann \& Eledu, 1999).

\subsection{Cumulative Daily Rainfall during Experimentation in Namayingo and Tororo Districts}

The total daily cumulative rainfall for Tororo district in the seasons 2011B (419 mm) and 2012A (447 mm) were similar but lower than that received in Namayingo during similar seasons, 2011B (543 mm) and 2012A (605 mm) (Figure 1). In both sites, rainfall distribution patterns during each season were similar although amounts received in Tororo were under sub humid climate.

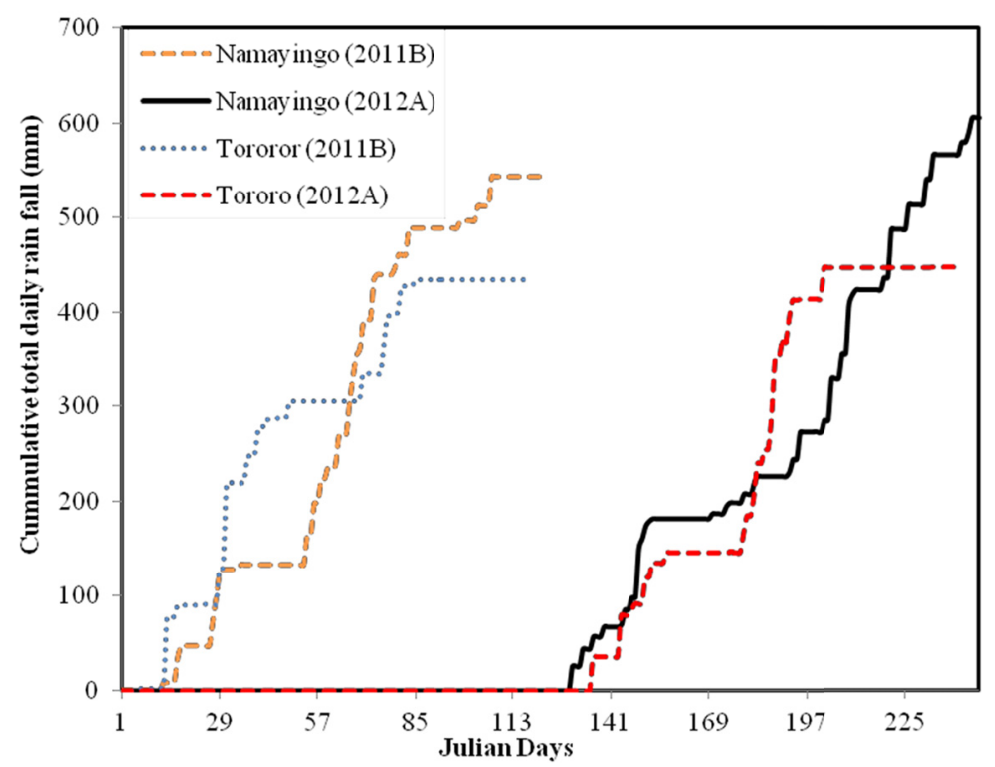

Figure 1. Cumulative daily rainfall received during experimentation during 2011B and 2012A seasons in Namayingo and Tororo districts

\subsection{Soil Sampling, Soybean Residue Characterization and Analyses}

Soil samples were taken from five farmer fields at Namayuge and Nyemnyemi villages in Namayingo and Tororo districts respectively. Random soil samples were taken from five spots at $0-20 \mathrm{~cm}$ depth in each farmer field to obtain composite samples of approximately $0.5 \mathrm{~kg}$. The composite samples were air-dried, ground and sieved through $2 \mathrm{~mm}$ sieve and then subjected to analyses of soil $\mathrm{pH}$, soil organic matter, Total $\mathrm{N}$, extractable $\mathrm{P}$, exchangeable bases and soil texture at Makerere University Soil and Plant analytical Laboratory. Soil pH was measured in a soil water solution at a ratio of 1:2.5; soil organic matter was determined by potassium dichromate wet acid oxidation method (Walkley \& Black, 1934), total $\mathrm{N}$ by Kjeldhal digestion (Bremner,1960).

Extractable P by Bray P1 method (Bray \& Kurtz, 1945), exchangeable bases $\left(\mathrm{K}^{+}, \mathrm{Na}^{+}\right)$from an ammonium acetate extract by flame photometry (Hanway \& Heidel, 1952) and atomic absorptionSpectrophotometry (Macphee \& Ball, 1967) for $\mathrm{Ca}^{2+}$ and $\mathrm{Mg}^{2+}$ ions and particle size distribution (texture) using the Bouyoucos (hydrometer) 
method (Bouyoucos, 1936). Soybean residues from each farmer's homestead were bulked and composite soybean residue samples were collected, oven-dried at $70{ }^{\circ} \mathrm{C}$, ground into fine powder and sieved through a 0.5 $\mathrm{mm}$ sieve prior to analysis of total $\mathrm{N}, \mathrm{P}$ and $\mathrm{K}$. Total $\mathrm{N}$ and $\mathrm{P}$ were analyzed from micro-Kjeldhal digests with $\mathrm{H}_{2} \mathrm{SO} 4$ and $\mathrm{H}_{2} \mathrm{O}_{2}$ followed by steam distillation and titration with $\mathrm{HCL}$ for $\mathrm{N}$, and by colorimetry (molybdenum-blue) for $\mathrm{P}$ and $\mathrm{K}$ by atomic absorption spectrophotometry. The initial analysis of the soils at both Namayingo and Tororo experimental sites showed moderately acidic soils with soil $\mathrm{pH}$ values above the critical value of 5.5 (Foster, 1971), rich in exchangeable bases though soil organic carbon and extractable Bray-1P was below the critical of $10 \mathrm{mg} \mathrm{kg}^{-1}$ at both sites (Table 1). The soil texture in Namayingo was loam while that at Tororo was sandy loam. Generally, the soils from both sites were of low fertility (Foster, 1981; Ssali, 2002) and are often less productive Petric Plinthsols. Soybean residue differed significantly $(p<0.05)$ in N content at the two sites (Table 2). This information was later used as a basis to apportion required fertilizer rates for the different study sites.

\subsection{Establishment and Management of the Field Experiments}

Field experiments were conducted for two seasons (2011B and 2012A) in the two study sites. In the second season (2012A), the residual effects of the nutrients applied in the first season (2011B) were assessed. In the first season, the fields were ox-ploughed, harrowed and plot sizes of $5 \times 5 \mathrm{~m}$ demarcated and in the second season land preparation was done on plot basis using a hand hoe. In both seasons, a randomized complete block design was used with a $3 \times 4$ factorial treatment structure. Four experimental gardens hosted by farmers were replicates in each of the sites (Namayingo and Tororo). The treatments included three levels soybean residue applied at 0,2 and $4 \mathrm{tha}^{-1}$ and four levels of urea (used as $\mathrm{N}$ source) at $0,30,60$ and $120 \mathrm{~kg} \mathrm{ha} \mathrm{N}^{-1}$. The treatment combinations were $2 \mathrm{tha}^{-1}$ of soybean residue with three levels of $\mathrm{N}\left(30 \mathrm{~N}, 60 \mathrm{~N}\right.$, and $\left.120 \mathrm{~kg} \mathrm{ha} \mathrm{N}^{-1}\right)$ and $4 \mathrm{tha}^{-1}$ of soybean residue with three levels of $\mathrm{N}\left(30 \mathrm{~N}, 60 \mathrm{~N}, \& 120 \mathrm{~kg} \mathrm{ha} \mathrm{N}^{-1}\right)$. The test crop was (DH04), a Kenyan hybrid maize variety that is tolerant to striga weed. The quantities of the residues applied were on dry matter basis after adjusting to $12 \%$ moisture content. The experiments were planted in September, 2011 short rainy season (season B) and March, 2012 for the long rainy season (2012A season). All the experiments were planted at a recommended spacing of $75 \times 50 \mathrm{~cm}$ with two plants per hill and plot sizes of $5 \times 5 \mathrm{~m}$ at both sites. Agronomic management practices were done as recommended, for example, weeding was done twice, $\mathrm{N}$ fertilizer rates in form of urea and potassium in form of muriate of potash were applied in two equal splits; at planting and five weeks after planting, while Phosphorus fertilizer was applied as a basal at recommended rate of $45 \mathrm{~kg} \mathrm{P} \mathrm{ha}^{-1}$ in all the plots with exception of the control plots in the first season. The first split of $\mathrm{N}$ fertilizer applied was to enhance decomposition of the soybean residue. This is because soybean residues have $<2.5 \% \mathrm{~N}$ (Palm et al., 2001).

Table 1. Initial soil characteristics of experimental sites

\begin{tabular}{lllllllllll}
\hline Site & $\mathrm{pH}\left(\mathrm{H}_{2} \mathrm{O}\right)$ & $\mathrm{SOC}$ & Bray 1 P & $\mathrm{K}$ & $\mathrm{Na}$ & $\mathrm{Ca}$ & $\mathrm{Mg}$ & $\mathrm{Sand}$ & Silt & Clay \\
\hline & & $\mathrm{g} \mathrm{kg}^{-1}$ & $\mathrm{mg} \mathrm{kg}^{-1}$ & --- Exchangeable bases $\left(\mathrm{cmol} \mathrm{kg}^{-1}\right)$ & --- & ------ & Texture $\left(\mathrm{g} \mathrm{kg}^{-1}\right)------$ \\
Namayingo & 5.81 & $18 \pm 0.3$ & $2.8 \pm 0.5$ & $0.5 \pm 0.1$ & $0.8 \pm 0.02$ & $7.5 \pm 0.4$ & $3.1 \pm 0.4$ & $420 \pm 4.7$ & $330 \pm 3.7$ & $250 \pm 8.5$ \\
Tororo & 5.78 & $10 \pm 0.5$ & $1.0 \pm 8.7$ & $0.5 \pm 0.1$ & $0.8 \pm 0.03$ & $5.6 \pm 0.1$ & $2.1 \pm 0.1$ & $730 \pm 4.6$ & $120 \pm 2.0$ & $150 \pm 3.1$ \\
Critical values & $\mathbf{5 . 5}$ & $\mathbf{3 0}$ & $\mathbf{1 5}$ & $\mathbf{0 . 4}$ & $\mathbf{0 . 2}$ & $\mathbf{0 . 4 4}$ & $\mathbf{0 . 4}$ & $\mathrm{NA}$ & $\mathrm{NA}$ & $\mathrm{NA}$
\end{tabular}

Note. $\mathrm{NA}=$ Not Available, Values are $\mathrm{M} \pm \mathrm{SD}$ (Means \pm Standard Deviation).

Table 2. Chemical characteristics of soybean residues used in experimental fields

\begin{tabular}{llll}
\hline \multirow{2}{*}{ Site } & \multicolumn{3}{c}{ \% Total } \\
\cline { 2 - 4 } & $\mathrm{N}$ & $\mathrm{P}$ & $\mathrm{K}$ \\
\hline Namayingo $(n=5)$ & $1.1 \pm 0.3$ & $0.5 \pm 0.4$ & $1.1 \pm 0.4$ \\
Tororo $(n=5)$ & $0.6 \pm 0.1$ & $0.6 \pm 0.3$ & $1.0 \pm 0.1$ \\
\hline
\end{tabular}

Note. Values are $\mathrm{M} \pm \mathrm{SD}$ (Means \pm Standard Deviation).

\subsection{Data Collection and Analysis}

\subsubsection{Grain and Stover Yield Analyses}

Maize yield data was collected at physiological maturity from four farmer fields $(n=4)$ at both Tororo and Namayingo districts. Three inner rows of each plot constituting a sampling area of $2.25 \times 4 \mathrm{~m}$ were used per plot. 
The plant stand count of the selected rows of each field was conducted to establish the number of plants per plot. The plants for analysis were cut at ground level leaving out three plants at the edges of the plots (the first and the last plants of each selected row) to minimize border effect. Total above ground biomass including cobs after threshing and stover were harvested oven dried at $7{ }^{\circ} \mathrm{C}$ for $72 \mathrm{hrs}$. The oven-dry weight was measured and used to adjust the grain and stover yields to $12 \%$ moisture content.

2.5.2 Quantification of the Added Yield Benefits Derived From Combined Application of Soybean Residue With $\mathrm{N}$ Fertilizer

Added benefits were calculated following an equation adapted from Vanlauwe et al. (2001) as;

$$
\mathrm{AB}=\mathrm{Ycomb}-(\text { Yfert }- \text { Ycont })-(\text { Yresidue }- \text { Ycont })-\text { Ycont }
$$

Where, $\mathrm{AB}=$ Added Benefits, $\mathrm{Ycomb}=$ mean yield from combined use of $\mathrm{N}$ fertilizer and soybean residue, $\mathrm{Y}$ fert $=$ mean yield from sole $\mathrm{N}$ fertilizer, Ycont $=$ mean yield from the control treatment, and Yresidue $=$ mean yield from sole soybean residue.

All the data collected were subjected to analysis of variance using the GENSTAT statistical package of $11^{\text {th }}$ edition. The sole $\mathrm{N} \times$ sole residue interactions for both grain and stover maize yields were considered while for season, joint analyses were done since the seasons were different. Means were separated using Fisher' Protected Least Significant Difference (LSD) at 5\% probability levels (K. A. Gomez \& A. A. Gomez, 1984).

\section{Results}

3.1 Effect of sole Soybean Residue, N Fertilizer and Combinations of Soybean Residue With N Fertilizer on Average Maize Grain and Dry Matter Yield in Namayingo and Tororo Districts

Average maize grain yield varied significantly $(\mathrm{p}<0.001)$ with the additions of sole nitrogen fertilizer, sole soybean residue $(\mathrm{p}<0.001)$ and combinations of $\mathrm{N}$ fertilizer with soybean residue $(\mathrm{p}<0.001)$ in Namayingo district (Table 3). Maize grain yield increased by $85.71 \%, 71.72 \%, 67.98 \%$ and $44.48 \%$ above the control yields following the order of sole $\mathrm{N}$ fertilizer at $60 \mathrm{~kg} \mathrm{ha}^{-1} \mathrm{~N}>2 \mathrm{t} \mathrm{ha}^{-1}$ residue combined with $60 \mathrm{~kg} \mathrm{ha}^{-1} \mathrm{~N}>$ combination of $4 \mathrm{tha}^{-1}$ residue with $60 \mathrm{~kg} \mathrm{ha}^{-1} \mathrm{~N}$ and sole soybean residue at $4 \mathrm{tha}^{-1}$ residue respectively across the two seasons. Hence, highest maize grain increments were obtained with application of sole $\mathrm{N}$ fertilizer at 60 $\mathrm{kg} \mathrm{ha}^{-1} \mathrm{~N}(85.71 \%$ above the control $)$ and a combination of $2 \mathrm{t} \mathrm{ha}^{-1}$ residue with $60 \mathrm{~kg} \mathrm{ha}^{-1} \mathrm{~N}(71.72 \%$ above the control). For sole $\mathrm{N}$ fertilizer, highest dry matter yield increment $(93.75 \%$ above the control) was obtained at sole $\mathrm{N}$ fertilizer at $60 \mathrm{~kg} \mathrm{ha}^{-1} \mathrm{~N}$ while for sole residue, combination of $2 \mathrm{tha}^{-1}$ residue, $4 \mathrm{tha}^{-1}$ residue with $\mathrm{N}$ fertilizer occurred at highest nutrient combination rates (dry matter yield increased by $64.41 \%$ above the control for sole $4 \mathrm{tha}^{-1}$ residue, $99.49 \%$ and $102.10 \%$ increment of dry matter yield above the control with a combined application of $2 \mathrm{tha}^{-1}$ residue with $120 \mathrm{~kg} \mathrm{ha}^{-1} \mathrm{~N}$ and $4 \mathrm{tha}^{-1}$ residue with $120 \mathrm{~kg} \mathrm{ha}^{-1} \mathrm{~N}$ ) respectively.

Table 3. Effect of sole soybean residue, $\mathrm{N}$ fertilizer and combinations of soybean residue with $\mathrm{N}$ fertilizer on average maize grain and dry matter yield across two seasons in Namayingo district

\begin{tabular}{|c|c|c|c|c|c|}
\hline N-Rates $\left(\mathrm{kg} \mathrm{ha}^{-1}\right)$ & Residue-Rates $\left(\mathrm{t} \mathrm{ha}^{-1}\right)$ & Sole N & Sole Residues & $2 \mathrm{t}+\mathrm{N}$ & $4 \mathrm{t}+\mathrm{N}$ \\
\hline & & \multicolumn{4}{|c|}{-------------------- Grain Yield $\left(\mathrm{t} \mathrm{ha}^{-1}\right.$ ) ------------------- } \\
\hline 0 & 0 & 1.63 & 1.63 & 1.63 & 1.63 \\
\hline 30 & $2 \mathrm{t}$ & 2.12 & 2.12 & 2.38 & 2.25 \\
\hline 60 & $4 \mathrm{t}$ & 3.03 & 2.36 & 2.80 & 2.74 \\
\hline 120 & & 2.43 & & 2.91 & 2.78 \\
\hline P-Value & & 0.001 & 0.001 & 0.001 & \\
\hline $\operatorname{LSD}(0.05)$ & & 0.140 & 0.121 & 0.242 & \\
\hline & & \multicolumn{4}{|c|}{ Dry Matter Yield $\left(\mathrm{t} \mathrm{ha}^{-1}\right)$ - } \\
\hline 0 & 0 & 2.72 & 2.72 & 2.72 & 2.72 \\
\hline 30 & $2 \mathrm{t}$ & 4.00 & 4.26 & 4.57 & 3.70 \\
\hline 60 & $4 \mathrm{t}$ & 5.27 & 4.47 & 4.62 & 4.98 \\
\hline 120 & & 4.30 & & 5.43 & 5.50 \\
\hline P-Value & & 0.001 & 0.005 & 0.001 & \\
\hline $\operatorname{LSD}(0.05)$ & & 0.487 & 0.422 & 0.843 & \\
\hline
\end{tabular}

In Tororo district, average maize grain yield varied significantly $(p<0.001)$ only with the additions of sole nitrogen fertilizer and sole soybean residue $(\mathrm{p}<0.001)$ with no significant interactions due to combinations of $\mathrm{N}$ 
fertilizer with soybean residue on maize grain yield (Table 4). However, maize grain yield increased with increase in soil input rates. Sole $\mathrm{N}$ fertilizer at $120 \mathrm{~kg} \mathrm{ha}^{-1} \mathrm{~N}$ increased average maize grain yield by $100.10 \%, 2 \mathrm{t}$ $\mathrm{ha}^{-1}$ residue combined with $120 \mathrm{~kg} \mathrm{ha}^{-1} \mathrm{~N}$ increased by $115.10 \%$ and $4 \mathrm{tha}^{-1}$ residue combined with $120 \mathrm{~kg} \mathrm{ha}^{-1} \mathrm{~N}$ increased by $140.69 \%$ above the control yield. That is, highest grain yields were obtained with addition of highest input rates. Addition of sole soybean residue at $2 \mathrm{t} \mathrm{ha}^{-1}$ residue increased maize grain yield by $49.80 \%$ above the control. For dry matter yield, average dry matter yield increased significantly $(\mathrm{p}<0.001)$ with application of the soil amendments (Table 4). Dry matter yield increased by $74.62 \%, 109.09 \%$ and $134.59 \%$ above the control yield with sole $\mathrm{N}$ fertilizer at $120 \mathrm{~kg} \mathrm{ha}^{-1} \mathrm{~N}, 2 \mathrm{t} \mathrm{ha}^{-1}$ residue combined with $120 \mathrm{~kg} \mathrm{ha}^{-1} \mathrm{~N}$ and 4 $\mathrm{t} \mathrm{ha}^{-1}$ residue combined with $120 \mathrm{~kg} \mathrm{ha}^{-1} \mathrm{~N}$ respectively. Similar to maize grain yield, highest average dry matter yield increment of $62.20 \%$ above the control yield was obtained at $2 \mathrm{t} \mathrm{ha}^{-1}$ residue (Table 4).

Table 4. Effect of sole soybean residue, $\mathrm{N}$ fertilizer and combinations of soybean residue with $\mathrm{N}$ fertilizer on average maize grain and dry matter yield in Tororo district

\begin{tabular}{|c|c|c|c|c|c|}
\hline N-Rates $\left(\mathrm{kg} \mathrm{ha}^{-1}\right)$ & Residue-Rates $\left(\mathrm{t} \mathrm{ha}^{-1}\right)$ & Sole N & Sole Residues & $2 \mathrm{t}+\mathrm{N}$ & $4 \mathrm{t}+\mathrm{N}$ \\
\hline & & \multicolumn{4}{|c|}{ - } \\
\hline 0 & 0 & 1.02 & 1.02 & 1.02 & 1.02 \\
\hline 30 & $2 \mathrm{t}$ & 1.41 & 1.52 & 1.76 & 1.82 \\
\hline 60 & $4 \mathrm{t}$ & 1.57 & 1.47 & 1.98 & 2.29 \\
\hline 120 & & 2.04 & & 2.19 & 2.46 \\
\hline P-Value & & 0.001 & 0.001 & 0.216 & \\
\hline \multirow[t]{2}{*}{$\operatorname{LSD}(0.05)$} & & 0.151 & 0.130 & 0.261 & \\
\hline & & \multicolumn{4}{|c|}{ Dry Matter Yield $\left(\mathrm{t} \mathrm{ha}^{-1}\right)$ - } \\
\hline 0 & 0 & 1.65 & 1.65 & 1.65 & 1.65 \\
\hline 30 & $2 \mathrm{t}$ & 2.44 & 2.68 & 2.86 & 3.33 \\
\hline 60 & $4 \mathrm{t}$ & 2.36 & 2.38 & 3.15 & 3.69 \\
\hline 120 & & 2.88 & & 3.45 & 3.87 \\
\hline P-Value & & 0.001 & 0.001 & 0.573 & \\
\hline $\operatorname{LSD}(0.05)$ & & 0.365 & 0.316 & 0.632 & \\
\hline
\end{tabular}

\subsection{Added Grain Yield Benefits Arising From Combined Application of Soybean Residue With N Fertilizer in Namayingo and Tororo Districts}

The interactive benefits arising from the combined application of soybean residues with $\mathrm{N}$ fertilizer were generally positive across the two sites (Figure 2). Added grain yield benefits were obtained with a combinations of $2 \mathrm{t} \mathrm{ha}^{-1}$ residue with $\mathrm{N}$ fertilizer at $30 \mathrm{~kg} \mathrm{ha}^{-1} \mathrm{~N}\left(3030 \mathrm{~kg}_{\text {grain ha }}{ }^{-1}\right), 60 \mathrm{~kg} \mathrm{ha}^{-1} \mathrm{~N}\left(2540 \mathrm{~kg}_{\text {grain ha }}{ }^{-1}\right)$ and 120 $\mathrm{kg} \mathrm{ha}^{-1} \mathrm{~N}\left(3250 \mathrm{~kg}\right.$ grain ha $\left.{ }^{-1}\right)$ respectively in Namayingo (Figure 2a) as compared to a combination of $4 \mathrm{tha}^{-1}$ residue with $\mathrm{N}$ fertilizer at $30 \mathrm{~kg} \mathrm{ha}^{-1} \mathrm{~N}\left(2660 \mathrm{~kg}_{\text {grain ha }}{ }^{-1}\right), 60 \mathrm{~kg} \mathrm{ha}^{-1} \mathrm{~N}\left(2240 \mathrm{~kg}\right.$ grain ha $\left.{ }^{-1}\right)$ and $120 \mathrm{~kg} \mathrm{ha}^{-1} \mathrm{~N}$ $\left(2280 \mathrm{~kg}\right.$ grain $\mathrm{ha}^{-1}$ ) (Figure 2a). However, the highest added grain yield benefit was obtained with a combination of $2 \mathrm{t} \mathrm{ha}^{-1}$ residue with $\mathrm{N}$ fertilizer at $120 \mathrm{~kg} \mathrm{ha}^{-1} \mathrm{~N}\left(3250 \mathrm{~kg}_{\text {grain ha }}{ }^{-1}\right)$. In Tororo, added grain yield benefits were obtained with a combinations of $4 \mathrm{t} \mathrm{ha}^{-1}$ residue with $\mathrm{N}$ fertilizer at $30 \mathrm{~kg} \mathrm{ha}^{-1} \mathrm{~N}(2000 \mathrm{~kg}$ grain ha- $\left.{ }^{-1}\right), 60 \mathrm{~kg} \mathrm{ha}^{-1} \mathrm{~N}\left(2310 \mathrm{~kg}_{\text {grain ha }}{ }^{-1}\right)$ and $120 \mathrm{~kg} \mathrm{ha}^{-1} \mathrm{~N}\left(2100 \mathrm{~kg}_{\text {grain ha }}{ }^{-1}\right)$ respectively (Figure $\left.2 \mathrm{~b}\right)$ as compared to a combination of $2 \mathrm{tha}^{-1}$ residue with $\mathrm{N}$ fertilizer at $30 \mathrm{~kg} \mathrm{ha}^{-1} \mathrm{~N}\left(1890 \mathrm{~kg}_{\text {grain ha }}{ }^{-1}\right), 60 \mathrm{~kg} \mathrm{ha}^{-1} \mathrm{~N}$ $\left(1950 \mathrm{~kg}\right.$ grain ha $\left.{ }^{-1}\right)$ and $120 \mathrm{~kg} \mathrm{ha}^{-1} \mathrm{~N}\left(1690 \mathrm{~kg}_{\text {grain }} \mathrm{h}^{-1}\right.$ ) (Figure $\left.2 \mathrm{~b}\right)$ and the highest added grain yield benefit was obtained with a combination of $4 \mathrm{tha}^{-1}$ residue with $\mathrm{N}$ fertilizer at $60 \mathrm{~kg} \mathrm{ha}^{-1} \mathrm{~N}\left(2310 \mathrm{~kg}_{\text {grain ha }}{ }^{-1}\right)$. 


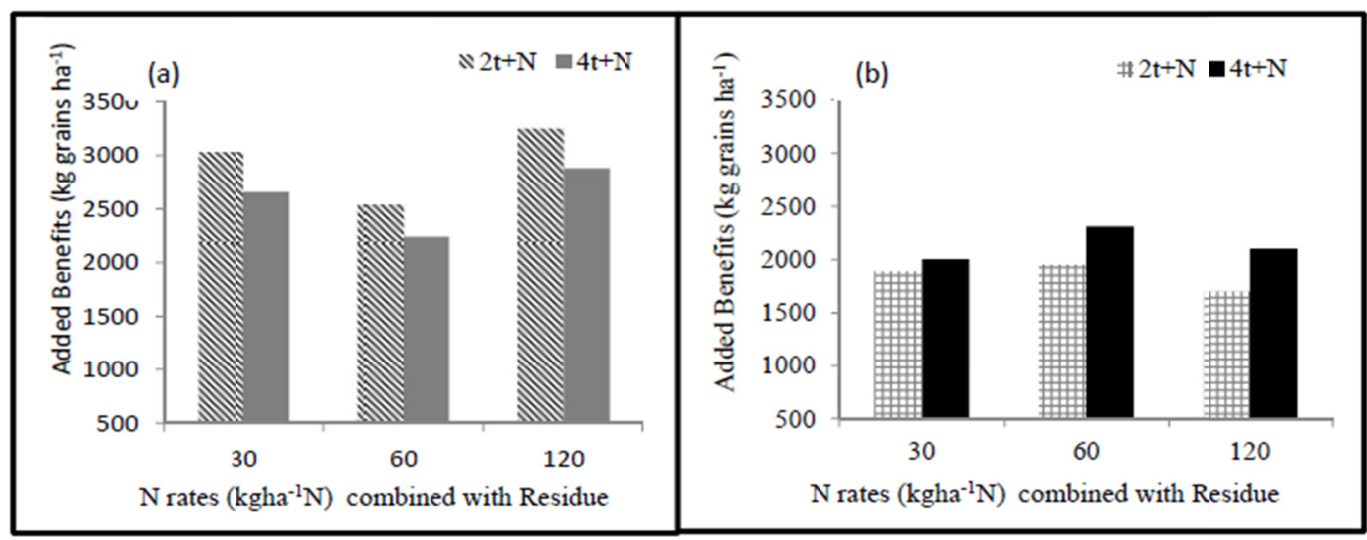

Figure 2. Added maize grain yield benefits from combined application of soybean residues with $\mathrm{N}$ fertilizer in Namayingo (a) and Tororo (b) districts. $\left(\mathrm{N}\right.$ rates) $=0,30,60,120 \mathrm{~kg} \mathrm{ha} \mathrm{N}^{-1}\left(2 \mathrm{t}=2 \mathrm{tha}^{-1}\right.$ soybean residues $=18$ $\mathrm{kg} \mathrm{N}$ and $4 \mathrm{t}=4 \mathrm{t} \mathrm{ha}^{-1}$ soybean residues $=36 \mathrm{~kg} \mathrm{~N}$ ) based on the nitrogen content of soybean residues (Table 2)

\section{Discussion}

\subsection{Mean Maize Yields Across Seasons in Namayingo and Tororo Districts}

Highest average maize grain yield increments were obtained with higher sole $\mathrm{N}$ fertilizer rates of $60 \mathrm{~kg} \mathrm{ha}^{-1} \mathrm{~N}$ and at $120 \mathrm{~kg} \mathrm{ha}^{-1} \mathrm{~N}(85.71 \%$ and $100.10 \%$ above the control) for Namayingo and Tororo districts respectively (Tables 3 and 4), with higher maize grain yields obtained from Namayingo as compared to Tororo. The site yield differences could be due to the differences in soil texture. Thus, the sandy loam soil texture characterized with poor water holding and cation exchange capacities in Tororo as compared to the sandy clay loam soils of Namayingo with a higher water holding and nutrient retention capacities (Wolkowski et al., 1995) contributed to the observed yield difeferences. Apparently, soil texture is among the indices that influence the inherent fertility status of fields with the ability of fine textured soils to hold and retain water and nutrient stocks better thereby influencing the positive yield responses of crops to applied nutrient inputs. (Bationo et al., 2007) as compared to course textured soils indicative of less fertile soils in Tororo that could have enhanced nutrient losses through runoff thereby, requiring more $\mathrm{N}$ rates to enhance maize yields in Tororo than in Namayingo. Ebanyat (2009) similarly reported low finger millet yields from Pallisa Eastern Uganda due to degraded fields that required more soil input amendments for improved crop yields. Furthermore, Mtambanengwe et al. (2006) reported differences in yield increases when $\mathrm{N}$ fertilizer was applied with sunn-hemp (Crotolaria juncea $\mathrm{L}$.) in fine and coarse textured soils.The fine textured soils recorded higher yield increases than in the sandy and coarse textured soils because of the higher nutrient stocks in the fine textured soils than the sandy textured inherently infertile soils.. In addition, the highest maize grain yields obtained from sole application of $\mathrm{N}$ fertilizer could probably be attributed to the ability of inorganic fertilizer to supply readily available nutrients for immediate plant uptake unlike the organic inputs that release nutrients slowly to improve soil physical, chemical and biological properties in the longer period. More so, this study was conducted for only two seasons where the second season focused at the residual effects of the applied soil inputs hence the reported yield responses due to sole $\mathrm{N}$ fertilizer application at both sites. Generally, maize yield responses were least with sole use of organic materials as compared to inorganic $\mathrm{N}$ fertilizer and integrated use of the soil amendments (Tables 3 and 4 ) in Namayingo and Tororo respectively. This is because the organic materials mainly tend to improve soil organic carbon content and soil physical properties in a much longer period than in two cropping seasons. Hence the two cropping seasons conducted for this study could have not been sufficient enough to enhance soybean residue decomposition given the relatively high carbon to nitrogen ratio of approximately 15:1. Other research findings indicate that time, $\mathrm{C}: \mathrm{N}$ ratio and temperatures are key parameters in residue decomposition (Al-Kaisi et al., 2014) therefore, much as the temperatures in the study areas were adequate, the $\mathrm{C}: \mathrm{N}$ ratio and time factors could have contributed to the low yields obtained from sole soybean residue additions. Though sole $\mathrm{N}$ fertilizer avails nutrients immediately for plant uptake, there are higher risks to losses through runoff and leaching (Vanlauwe et al., 2001; Shroder, 2005) given the moderately high rainfall received during the time of experimentation (Figure 1). Combined application of $\mathrm{N}$ fertilizer with soybean residue resulted in highest maize yields at highest nutrient input rates in Tororo district probably due to more nutrient depleted soils in Tororo that require higher soil nutrient rates to improve maize yields. It is also liley that the soybean residue used required higher nitrogen input rates to aid mineralization and consequently nutrient release for plant uptake. Okalebo et al. (1999), and 
Schoessow et al. (2010) reported higher maize yields from combined application of soybean residues with $\mathrm{N}$ fertilizer at $\mathrm{N}$ rates greater than $80 \mathrm{~kg} \mathrm{~N} \mathrm{ha}{ }^{-1}$. The implication could be that maize yield enhancement with combined application of soybean residue with $\mathrm{N}$ fertilizer is achievable at high $\mathrm{N}$ fertilizer rates more especially if applied in fields that are depleted of soil nutrients. The findings are consistent with Ebanyat (2009) who reported that degraded fields require high soil input nutrient rates to enhance crop yields. Furthermore, the decision support tool for organic materials recommends for integrated use of low to medium quality crop residues with $\mathrm{N}$ fertilizer or high quality organic materials (Palm et al., 2001). The findings are in agreement with Al-Kaisi et al. (2014) that crop residues with C:N ratios of about 15:1 are easily mineralized by soil microbes and consequently release nutrients for plant uptake hence the significantly high yield increments obtained from the integrated application of soybean residue with $\mathrm{N}$ fertilizer. This implies that, in addition to C:N ratio and temperature as factors that affect crop residue decomposition, the fertility status of the fields onto which the crop residues are to be applied must be considered. The research findings indicate that integrated use of medium quality crop residues particularly soybean residues integrated with $\mathrm{N}$ fertilizer only gives significantly high yields with addition of high input rates of $\mathrm{N}$ fertilizer. In Namayingo, highest maize yield increments occurred with the addition of $2 \mathrm{t} \mathrm{ha}^{-1}$ residue combined with $60 \mathrm{~kg} \mathrm{ha}^{-1} \mathrm{~N}(71.72 \%$ grain yield increment) (Table 3$)$ that could be attributed to higher amounts of total $\mathrm{N}$ recovered in the soybean residues (Table 2) and improved physical soil conditions attributed to soybean residues that work in synergism (Afridi et al., 2012). Similar findings have been reported by Muyayabantu et al. (2012) on combined used of N and P fertilizers with Tithonia diversifolia on maize in D.R. Congo that also accrued due to improved nutrient use and recovery efficiencies (Jan et al., 2007). In addition, Thind et al. (2019) reported high wheat yields when reduced tillage was combined with in-situ rice residue incorporation alongside with $150 \mathrm{~kg} \mathrm{ha}^{-1} \mathrm{~N}$ in a sandy loam soil of India since the high initial $\mathrm{N}$ rate promoted mineralization and subsequent nutrient release in the short term. Furthermore, Afridi et al. (2012) reported highest wheat grain yield from combined application of soybean residues with $100 \mathrm{~kg} \mathrm{ha}^{-1} \mathrm{~N}$ in Pakistan that was mainly attributed to increased decomposition and mineralization of the organic nitrogen from the soybean residues. The research findings concur with the findings of other researchers that integrated use of soybean residues with $\mathrm{N}$ fertilizer are agronomically beneficial at higher input combination rates particularly the $\mathrm{N}$ fertilizer rate of over $60 \mathrm{~kg} \mathrm{ha}^{-1} \mathrm{~N}$. Although the rates vary with the soil textural classes as more $\mathrm{N}$ rates (120 $\mathrm{kg} \mathrm{ha}^{-1} \mathrm{~N}$ ) combined with soybean residues resulted in higher maize grain yields in Tororo district that has sandy loam soils.

\subsection{Added Maize Grain Yield Benefits Arising From Combined Application of Soybean Residue With N Fertilizer in Namayingo and Tororo Districts}

The interactive benefits arising from the combined application of soybean residues with $\mathrm{N}$ fertilizers were mainly positive (Figure 2). The positive added grain yield benefits due to the combined application of soybean residues could have been attributed to better nutrient supply from both inorganic fertilizer and soybean residue that enhanced synchrony between nutrient supply, crop demand, nutrient utilization and consequently positive added yield benefits. In addition, since $\mathrm{K}$ and $\mathrm{P}$ fertilizers were blanket applied, there are possibilities that the $\mathrm{K}$ and $\mathrm{P}$ nutrients applied from triple superphosphate and muriat of potash could have influenced the uptake and responses of the added $\mathrm{N}$ fertilizer combined with the soybean residues thereby contributing to the added yield benefits. The findings are in agreement with previous findings that combined application of organic materials with fertilizers result in added yield benefits in terms of extra grain yields as compared to sole application of either nutrient input (Vanlauwe et al., 2001a, 2002b; Mucheru et al., 2002; Gentile et al., 2008). Also, chivenge et al. (2009) reported positive added maize grain yield from combined application of class III organic residues (sawdust and maize stover) with $\mathrm{N}$ fertilizer in central Kenya that gave positive added maize grain yields especially in a course textured less fertile soil (Mchanga site) typical of the study site (Tororo). This was attributed to the better soil conditions created by the addition of the residues given the sandy loam texture of the soils in Tororo similar to the Mchanga site of central Kenya hence the added positive maize grain yields obtained. Although some research findings have indicated negative interactions from combined application of $\mathrm{N}$ fertilizer with various organic materials for instance, saw dust and maize stover (class III organic residue) that often induce microbial $\mathrm{N}$ limitations since the organic residues are of low quality and have a high C:N ratio hence the negative interactive effects as a result of $\mathrm{N}$ immobilization. However, in this study, negative interactions were not obtained (Chivenge et al., 2009). Our findings indicate that class II organic residues typical of the soybean residues used in this study resulted in positive added maize grain yields though at higher input combination rates of $2 \mathrm{t} \mathrm{ha}^{-1}$ soybean residues with $60 \mathrm{~kg} \mathrm{ha}^{-1} \mathrm{~N}$ and $4 \mathrm{tha}^{-1}$ soybean residue with $120 \mathrm{~kg} \mathrm{ha}^{-1} \mathrm{~N}$ in Namayingo and Tororo districts respectively. Furthermore, negative interactions might also arise due to climatic factors such as excessive rainfall during the season that leach out the available nutrients hence the low added yields (Vanlauwe et al., 2002) as well as the fertility status of the fields. It is noteworthy that rainfall amount received during the 
experimentation was similar to the usual amounts received in the area thus ruling out aspects of nutrient losses through leaching and runoff hence the observed positive added maize grain yields at both sites.

\section{Conclusions}

Combining soybean residues with $\mathrm{N}$ fertilizer significantly improved maize yields at both study sites but the input rates varied with the sites. Generally, better maize grain yields were far better at higher nutrient combinations rates at both sites. In addition, positive maize grain yield benefits are possible with combined application of the nutrient inputs at higher than lower rates particularly if the fields are degraded. Nutrient decomposition studies are recommended for a clear understanding of nutrient release patterns in legume crop residues for maize production, including cost benefit studies on combined use of $\mathrm{N}$ fertilizer and soybean residue in a maize/soybean cropping system.

\section{Acknowledgements}

We are grateful to the Alliance for A Green Revolution in Africa support through the soil health project of Makerere University, Africa 2000 Network, the host farmers, field assistants who greatly contributed to the success of the research findings.

\section{References}

Afridi, M. Z., Khan, A., \& Akbar, H. (2012). Integrated management of crop residue and N fertilizer for wheat production. Pak. J. Bot., 44(6), 2015-2019.

Al-Kaisi, M. (2014). Myths and facts about residue breakdown. Iowa State University, Integrated Crop Management News.

Bationo, A., Kihara, J., Vanlauwe, B., Waswa, B., \& Kimetu, J. (2007). Soil organic carbon dynamics, functions and management in West African agro-ecosystems. Agricultural Systems, 94(1), 13-25. https://doi.org/ 10.1016/j.agsy.2005.08.011

Bouyoucos, G. J. (1936). Directions for making mechanical analysis of soils by the hydrometer method. Soil Sci., 42, 225-230. https://doi.org/10.1097/00010694-193609000-00007

Bray, R. H., \& Kurtz, L. T. (1945). Determination of total, organic, and available forms of phosphorus in soils. Soil Sci., 59, 39-45. https://doi.org/10.1097/00010694-194501000-00006

Bremner, J. M. (1960). Determination of nitrogen in soil by the Kjeldahl method. The Journal of Agricultural Science, 55(1), 11-33. https://doi.org/10.1017/S0021859600021572

Chivenge, P., Vanlauwe, B., \& Six, J. (2009). Does the combined application of organic and mineral nutrient sources influence maize productivity? A meta-analysis. Plant and Soil, 342(1-2), 1-30. https://doi.org/ 10.1007/s11104-010-0626-5

Ebanyat, P. (2009). A road to food? Efficacy of nutrient management options targeted to heterogeneous soilscapes in the Teso farming system, Uganda (Doctoral Thesis, Wageningen University, the Netherlands).

FAOSTAT. (2010). FAO Statistics Division 2010/06 November 2010.

Foster, H. L. (1971). Rapid routine soil and plant analysis without automatic equipment: Routine soil analysis. East Afr. Agric. For. J., 37, 160-170. https://doi.org/10.1080/00128325.1971.11662519

Foster, H. L. (1981). The basic factors which determine inherent soil fertility in Uganda. J. Soil Sci., 32, 149-160. https://doi.org/10.1111/j.1365-2389.1981.tb01693.x

Garrity, D. P., Akinnifesi, F. K., Ajayi, O. C., Weldesemayat, S. G., Mowo, J. G., Kalinganire, A., ... Bayala, J. (2010). Evergreen Agriculture: a robust approach to sustainable food security in Africa. Food Security, 2(3), 197-214. https://doi.org/10.1007/s12571-010-0070-7

Gentile, R., Vanlauwe, B., Chivenge, P., \& Six, J. (2008). Interactive effects from combining fertilizer and organic residue inputs on nitrogen transformations. Soil Biology and Biochemistry, 40(9), 2375-2384.

Gomez, K. A., \& Gomez, A. A. (1984). Statistical procedures for agricultural research (2nd ed.). J. Wiley and Sons, NewYork.

Hanway, J. J., \& Heidel, H. (1952). Soil analysis methods as used in Iowa state college soil testing laboratory. Iowa Agri, 57, 1-31. 
Jama, B., Palm, C. A., Buresh, R. J., Niang, A., Gachengo, C., Nziguheba, G., \& Amadalo, B. (2000). Tithonia diversifolia as a green manure for soil fertility improvement in western Kenya: A review. Agroforestry Systems, 49(2), 201-221. https://doi.org/10.1023/A:1006339025728

Jan, T., Jan, M. T., Arif, M., Akbar, H., \& Ali, S. (2007). Response of wheat to source, type and time of nitrogen application. Sarhad Journal Agriculture, 23, 871-879.

Kaizzi, K. C., Byalebeka, J., Semalulu, O., Alou, I., Zimwanguyizza, W., Nansamba, A., ... Wortmann, C. S. (2012). Maize response to fertilizer and nitrogen use efficiency in Uganda. Agronomy Journal, 104(1), 73-82. https://doi.org/10.2134/agronj2011.0182

Kaizzi, K. C., Byalebeka, J., Wortmann, C. S., \& Mamo, M. (2007). Low input approaches for soil fertility management in semiarid eastern Uganda. Agronomy Journal, 99(3), 847-853. https://doi.org/10.2134/ agronj2006.0238

Kamanga, B. C. G., Waddington, S. R., Robertson, M. J., \& Giller, K. E. (2010). Risk analysis of maize-legume crop combinations with smallholder farmers varying in resource endowment in central Malawi. Experimental Agriculture, 46(1), 1-21. https://doi.org/10.1017/S0014479709990469

Lal, R. (2005). World crop residues production and implications of its use as a biofuel. Environment International, 31(4), 575-584. https://doi.org/10.1016/j.envint.2004.09.005

Macphee, W. S. G., \& Ball, D. F. (1967). Routine determination of calcium and magnesium in soil extracts by atomic absorption spectrophotometry. Journal of the Science of Food and Agriculture, 18(8), 376-380. https://doi.org/10.1002/jsfa.2740180812

Mtambanengwe, F., \& Mapfumo, P. (2006). Effects of organic resource quality on soil profile $\mathrm{N}$ dynamics and maize yields on sandy soils in Zimbabwe. Plant and Soil, 281(1-2), 173-191. https://doi.org/10.1007/ s11104-005-4182-3

Mucheru, M., Mugendi, D., Micheni, A., Mugwe, J., Kung'u, J., Otor, S. \& Gitari, J. (2002). Improved food production by use of soil fertility amendment strategies in the central highlands of Kenya. Proceedings of the 8th meeting of the African Network for Soil Biology and Fertility research, Nairobi, Kenya (pp. 92-108).

Muna, M. M., Mugendi, D. N., Pypers, P., Mugwe, J., Kung'u, J., Vanlauwe, B., \& Merckx, R. (2013). Enhancing maize productivity and profitability using organic inputs and mineral fertilizer in Central Kenya small-hold farms.

Muyayabantu, G. M., Kadiata, B. D., \& Nkongolo, K. K. (2012). Response of maize to different organic and inorganic fertilization regimes in monocrop and intercrop systems in a sub-Saharan Africa region. Journal of Soil Science and Environmental Management, 3(2), 42-48.

Okalebo J. K., G. K. W., \& Woomer P. L. (2002). Laboratory Methods of Soil and Plant Analysis: A Working Manual (2 nd ed.). SACRED-Africa, Nairobi, Kenya.

Okalebo, J., Palm, C., Gichuru, M., Owuor, J., Othieno, C., Munyampundu, A., ... Woomer, P. (1999). Use of wheat straw, soybean trash and nitrogen fertiliser for maize production in the Kenyan highlands. African Crop Science Journal, 7, 423-431. https://doi.org/10.4314/acsj.v7i4.27736

Palm, C. A., Gachengo, C. N., Delve, R. J., Cadisch, G., \& Giller, K. E. (2001). Organic inputs for soil fertility management in tropical agroecosystems: Application of an organic resource database. Agriculture, Ecosystems \& Environment, 83(1-2), 27-42. https://doi.org/10.1016/S0167-8809(00)00267-X

Schoessow, K. A., Kilian, K. C., \& Bundy, L. G. (2010). Soybean Residue Management and Tillage Effects on Corn Yields and Response to Applied Nitrogen. Agronomy Journal, 102(4), 1186-1193. https://doi.org/ 10.2134/agronj2010.0033

Schröder, J. (2005). Revisiting the agronomic benefits of manure: A correct assessment and exploitation of its fertilizer value spares the environment. Bioresource Technology, 96(2), 253-261. https://doi.org/10.1016/ j.biortech.2004.05.015

Ssali, H. (2002). Soil organic matter and its relationship to soil fertility changes in Uganda. In E. M. Nkonya et al. (Eds.), Policies for improved land management in Uganda, Natl (2nd, pp. 99-102). Worksh.

Thind, H. S., Sharma, S., Singh, Y., \& Sidhu, H. S. (2019). Rice-wheat productivity and profitability with residue, tillage and green manure management. Nutrient Cycling in Agroecosystems, 113(2), 113-125. https://doi.org/ 10.1007/s10705-018-09967-8 
Van Vugt, D., Franke, A. C., \& Giller, K. E. (2017). Participatory research to close the soybean yield gap on smallholder farms in Malawi. Experimental Agriculture, 53(3), 396-415. https://doi.org/10.1017/ S0014479716000430

Vanlauwe, B., Aihou, K., Aman, S., Iwuafor, E. N., Tossah, B., Diels, J., ... Deckers, J. (2001). Maize yield as affected by organic inputs and urea in the West African moist savanna. Agronomy Journal, 93(6), 1191-1199. https://doi.org/10.2134/agronj2001.1191

Vanlauwe, B., Palm, C. A., Murwira, H. K., \& Merckx, R. (2002). Organic resource management in sub-Saharan Africa: validation of a residue quality-driven decision support system. Agronomie-Sciences des Productions Vegetales et de l'Environnement, 22(7-8), 839-846. https://doi.org/10.1051/agro:2002062

Waha, K., Müller, C., Bondeau, A., Dietrich, J. P., Kurukulasuriya, P., Heinke, J., \& Lotze-Campen, H. (2013). Adaptation to climate change through the choice of cropping system and sowing date in sub-Saharan Africa. Global Environmental Change, 23(1), 130-143. https://doi.org/10.1016/j.gloenvcha.2012.11.001

Wolkowski, R. P., Kelling, K. A., \& Bundy, L. G. (1995). Nitrogen management on sandy soils. University of Wisconsin-Extension.

Wortmann, C. S., \& Ssali, H. (2001). Integrated nutrient management for resource-poor farming systems: A case study of adaptive research and technology dissemination in Uganda. American Journal of Alternative Agriculture, 16(4), 161-167. https://doi.org/10.1017/S0889189300009140

Wortmann, C. S., \& Eledu, C. A. (1999). Uganda's agro ecological zones: A guide for planners and policy makers. CIAT, Kampala, Uganda.

\section{Appendix}

Table A1. Average maize yield response to nutrient input application in Namayingo district (average of two seasons)

\begin{tabular}{llllll}
\hline $\begin{array}{l}\text { Analysis of Variance } \\
\text { Variate: Dry Grain Yield_t/ha }\end{array}$ & \multicolumn{5}{l}{} \\
\hline Source of variation & d.f. & s.s. & m.s. & v.r. & F pr. \\
Replicate stratum & 3 & 0.41344 & 0.13781 & 2.35 & \\
Replicate.*Units* stratum & & & & & \\
Sole_N & 3 & 10.53563 & 3.51188 & 59.83 & $<.001$ \\
Sole_Residue & 2 & 1.25829 & 0.62914 & 10.72 & $<.001$ \\
Season & 1 & 23.02112 & 23.02112 & 392.2 & $<.001$ \\
Sole_N.Sole_Residue & $\mathbf{6}$ & $\mathbf{2 . 5 9 7 5 4}$ & $\mathbf{0 . 4 3 2 9 2}$ & $\mathbf{7 . 3 8}$ & $<.001$ \\
Sole_N.season & 3 & 0.24122 & 0.08041 & 1.37 & 0.259 \\
Sole_Residue.season & 2 & 1.51021 & 0.7551 & 12.86 & $<.001$ \\
Sole_N.Sole_Residue.season & 6 & 2.29042 & 0.38174 & 6.5 & $<.001$ \\
Residual & 69 & 4.05016 & 0.0587 & & \\
Total & 95 & 45.91803 & & & \\
\hline
\end{tabular}


Table A2. Average maize yield response to nutrient input application in Tororo district (average of two seasons)

\begin{tabular}{|c|c|c|c|c|c|}
\hline \multicolumn{6}{|l|}{$\begin{array}{l}\text { Analysis of Variance } \\
\text { Variate: Dry Grain Yield_t/ha }\end{array}$} \\
\hline Source of variation & d.f. & s.s. & m.s. & v.r. & F pr. \\
\hline Replicate stratum & 2 & 0.04871 & 0.02435 & 0.48 & \\
\hline \multicolumn{6}{|l|}{ Replicate.*Units* stratum } \\
\hline Sole_N & 3 & 7.89001 & 2.63 & 52.25 & $<.001$ \\
\hline Sole_Residue & 2 & 3.18823 & 1.59412 & 31.67 & $<.001$ \\
\hline Season & 1 & 60.08303 & 60.08303 & 1193.65 & $<.001$ \\
\hline Sole_N.Sole_Residue & 6 & 0.43853 & 0.07309 & 1.45 & 0.216 \\
\hline Sole_N.season & 3 & 2.43905 & 0.81302 & 16.15 & $<.001$ \\
\hline Sole_Residue.season & 2 & 0.93121 & 0.46561 & 9.25 & $<.001$ \\
\hline Sole_N.Sole_Residue.season & 6 & 0.2783 & 0.04638 & 0.92 & 0.488 \\
\hline Residual & 46 & 2.31544 & 0.05034 & & \\
\hline Total & 71 & 77.61253 & & & \\
\hline
\end{tabular}

\section{Copyrights}

Copyright for this article is retained by the author(s), with first publication rights granted to the journal.

This is an open-access article distributed under the terms and conditions of the Creative Commons Attribution license (http://creativecommons.org/licenses/by/4.0/). 